\title{
水撃圧による管の動的破壊と準静的破壊の実験的 比較研究
}

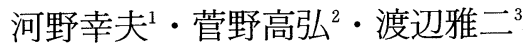 \\ 1 正会員 M.S. 東北学院大学助教授 工学部土木工学科 ( 9985 多賀城市中央一丁目) \\ 2 正会員 工博 運輸省港湾技術研究所 構造振動研究室 ( ₹239 横須賀市長瀬三丁目 1-1) \\ ${ }^{3} \mathrm{Ph}$. D. 岡山大学教授 理学部数学科（干700 岡山市津島中一丁目 1-1）
}

\begin{abstract}
管水路等で急閉鎖によって発生する水撃圧は急激な圧力上昇をもたらし、その水撃圧の影響による管等の破壊 は理論的に動的解析ということで, ほとんど解析されて来なかった. 本研究では水撃圧による動的破壊と静的破 壊とで, ビの程度の差異が現われるか, 実際に塩化ビニール管を破壊する実験を行った. その結果, 水撃破壊と 準静的破壊とで載荷時間が約 2000 倍の差がある場合, 水撃破壊の方が約 $25 \%$ 高い圧力で破壊した. 材料は塩 化ビニール管と限定した上ではあるが,一般的な水撃圧の載荷範囲内であれば急閉塞による水撃破壊に対しても, 静的な応力解析で破壊過程が表現でき, 設計上安全サイドであることを示した。
\end{abstract}

Key Words : water hammer, upstream finite difference method, dynamic pipe fracture, quasi-static pipe fracture, elastic analysis

\section{1. まえがき}

水撃圧に関する分野における最近の研究傾向として, 水撃圧の水理学的特質の解析と同時に, 管への作用に関 しての構造力学とのインターラクションの研究が少しず つ増えてきた。水撃压による管の破壊に関してはTullis $ら^{9)}$ や Davidson ら ${ }^{3)}$ の研究があるが，それらは管路 などの水撃圧と管破壊との関係についての研究であり視 点を水のみに置いたものである. また, 水理学的分野と 構造力学的分野とのインターラクションとしては Heinsbrook ら ${ }^{4)}$ の研究があるが，これらは水撃压による 管の振動やサポートの振動に関するものであり, 本研究 の目的である水撃圧による管の破壊に関しては未解明な 点が多いと思われる.

水撃圧によるダムのペンストック破壊事故や上水道管 路等の管破壊事故は水撃圧による管への載荷時間が問題 となる. 圧力トンネルの緩閉塞における水撃圧発生とそ の圧力による圧力トンネルの静的応力解析については以 前に文献 ${ }^{6}$ にて発表した. それは, 弁がある程度ゆっく りと閉塞する場合, 水撃圧も弁のゆっくりした閉塞につ れて徐々に圧力上昇をもたらすため, 圧力トンネル内の 水撃圧による岩盤に対する影響は静的応力解析で充分対 応できると考えた故である.

しかし，一般的な水撃圧は動的と考えられ，その水撃 圧の影響による管等の破壊は理論的に動的解析というこ とで，ほとんど解析されて来なかった，そこで，本研究
では水撃圧による管の動的破壊と水圧による準静的破壊 との間に，どの程度の差異が現われるかを知るために， 実際に，塩化ビニール管を用いた破壊実験を行った. 水 撃圧の解析への上流差分法の適用を試み，水撃波の圧力 と載荷時間について実験值との比較を行い, 有限要素法 による静的応力解析を行い, 実験值の準静的破壊強度お よび動的破壊強度との比較検討を行った。

\section{2. 水圧による管の準静的破壊試験}

\section{（1）供試体}

内径 $50 \mathrm{~mm}$, 厚さ $2 \mathrm{~mm}$ の塩化ビニール管を図一 1 の ように $300 \mathrm{~mm}$ の長さに切り落とし中央部分 $100 \mathrm{~mm}$ を 旋盤にて厚さ $0.4 \mathrm{~mm}$ まで削り落とす. 両端にネジのつ いたソケットを接着剤を用いて取付ける。この供試体は 水撃圧による動的破壊試験にも用いられる.

\section{（2）水圧による破壊試験装置と試験方法}

図一2 静圧破壊試験装置に示されるように供試体の両 端に圧力変換器が取付けられ, 載荷された水圧は波形記 憶装置で記憶されるようになっている.

供試体は 1. 鉄板で両端が固定され, 引っ張り力がか からない場合，2. 下端部が固定されず引つ張り力がか かる場合，また，3. 鉄板で両端が固定され引っ張り力 がかからないようになっているが, 固定する時偏心荷重 がかかった場合，の3ケースからなっているが，理論的 


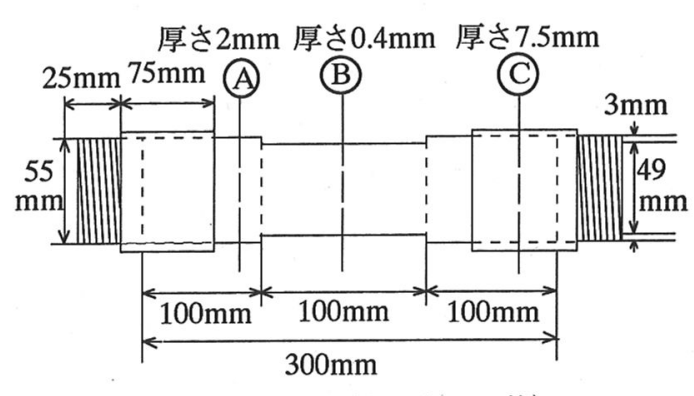

図一1 供試体（塩化ビニール管）

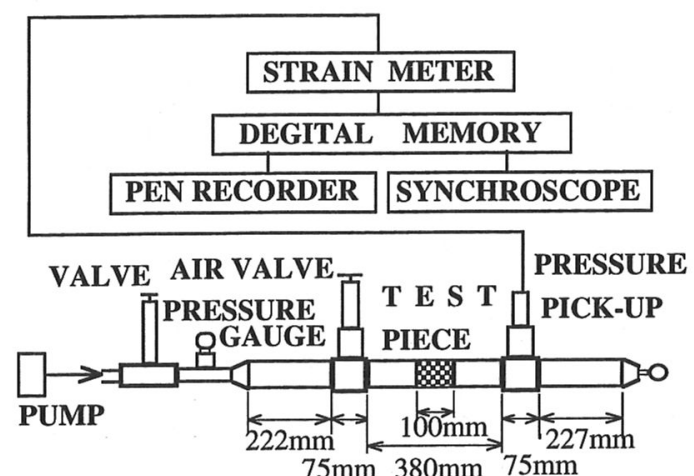

図一2 準静的破壊試験装置

解析における条件はケース 1 の場合で, 現場における管 の破壊はこの3 ケースが交じり合っている. 本研究では 理論的解析と比較検討するためケース 1 を中心に研究を 行う.

実験方法は載荷初期から破壊までの時間について約 2 分間を基準とし(それゆえに, 準静的という言葉を使用 している), 波形記憶装置の時間の設定を行い, ポンプ で載荷を行う。求圧は供試体の両端に設置された 2 個の 圧力変換器によって測定され, 動歪計で増幅され, 波形 記憶装置で記憶される. 水圧の準静的載荷により供試体 が破壊された後, シンクロスコープで波形をチエックし， ペンレコーダーにて波形を書き出し, 圧力時刻歴とする. この実験は同時にビデオカメラにて撮影され，ビデオに 取られた破壊過程, 破壊状況, ブルドン管式圧力計に示 される破壊圧力, 偏心荷重の有無および漏水等をチエッ クした後, 準静的破壊試験のデータとして採用した。 た, 破壊した管の状態, 破壊の開始した点, 飛び散った 水の到達点, 破壊した管の破片の大きさ, 飛び散り状況 および到達点等も管の破壊による影響範囲のデータとし て記録した。

\section{3. 準静的破壊試験の結果}

ケース1. 軸方向への引っ張りカが加わらないように

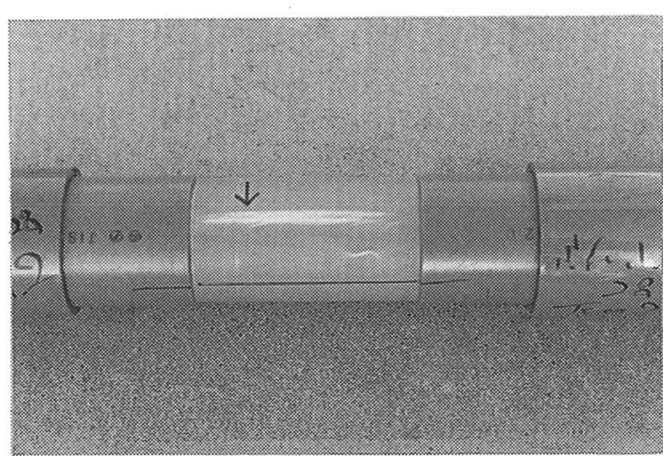

写真-1 破壊線

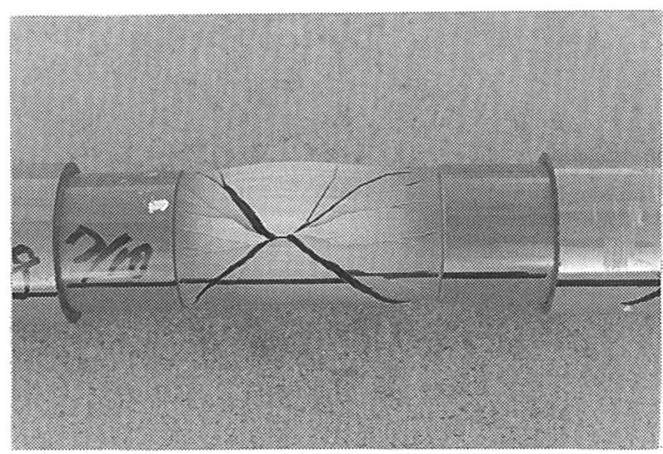

写真一2 破壊点と X 型亀裂

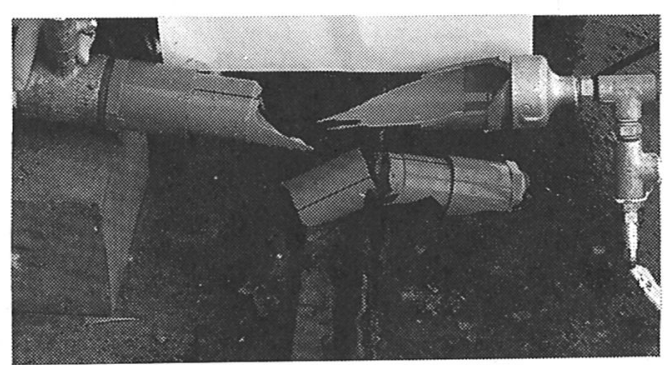

写真一3 厚さ 25 倍 $(7.5 \mathrm{~mm})$ の部分まで破壊したケース

供試体の両端を固定し，載荷時間を 2 分間とした場合, 管 29 本の平均破壊圧力は $11.57 \mathrm{kgf} / \mathrm{cm}^{2}(1.137 \mathrm{MPa})$ となった．軸方向への引っ張り力が加わらないように供 試体の両端を固定したが偏心荷重が加わった場合，管の 平均破壊圧力は $8.74 \mathrm{kgf} / \mathrm{cm}^{2}(0.857 \mathrm{MPa})$ となり, 偏心荷重が加わらなかった場合に較べると 2.83 $\mathrm{kgf} / \mathrm{cm}^{2}(0.278 \mathrm{MPa})$ 低い值で破壊した。

一般的に管の破壊は写真一1のように軸方向に一直線 に白い線が入り(破壞線), その上のある一点から破壊 が発生（破壞点）し，その点を中心として写真一2のよ うに八方にヒビが入り破壊するが，特に破壊点を中心に 対角線方向, X型に四方に向かって大きな亀裂が発生 し, その他の方向には小さな亀裂が数多く発生する. 破 壊点からX型に四方に向かって入った亀裂は厚さ 0.4 


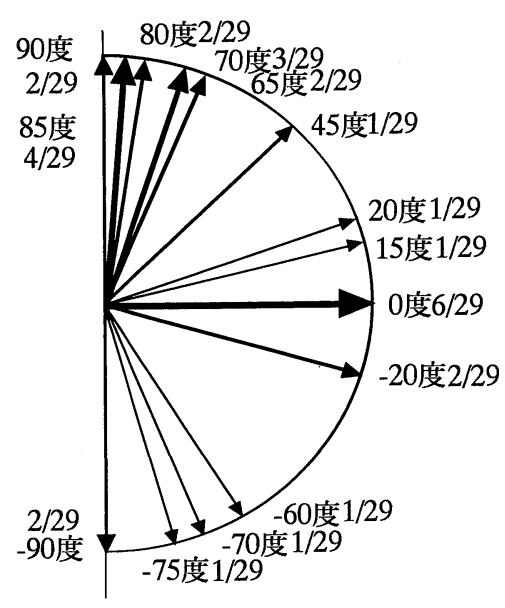

図一3 破壊発生点の位置と頻度

$\mathrm{mm}$ に削った面と厚さ $2 \mathrm{~mm}$ そのままの面との境界線ま で走り, それから下方に境界線に添って走り, 時には破 壊点の裏側全体が抜け落ちる様に破壊する。X型亀裂 部で軸方向の左右 90 度に入った亀裂は厚さ $0.4 \mathrm{~mm}$ と 厚さ $2 \mathrm{~mm}$ の境界も関係なく約 5 倍の厚さの部分にも亀 裂が入ってしまう。供試体の厚さ $0.3 \mathrm{~mm}$ の場合で引っ 張り力が働く時 $7.7 \mathrm{kgf} / \mathrm{cm}^{2}(7.55 \mathrm{MPa})$ の様な低い 圧力で破壊し, 写真一3のように塩化ビニール管とソ ケットとを接着した最も厚い約 $7.5 \mathrm{~mm}$ (この場合厚さ $0.3 \mathrm{~mm}$ で厚さの 25 倍）の部分やそれ以上厚い的じの 部分までも破壊される場合がある。この事より圧力はそ れほど高く無くとも，材質の欠陥などの初期不整の影響 で，ある一点で破壊が始まれば他の強度の高い部分まで もが破壊することがわかる．故に，高い珐力が発生する ような管路や重要管路においては材質の欠陥や初期不整 に十分注意を要するものと思われる.

軸方向への引つ張り力が加わらないように供試体の両 端を固定する場合, 固定に用いる鉄板のボルトの締め方 が均一でないと供試体に載荷前にすでに偏心荷重が加 わってしまう場合が生じる。このような場合には, 圧力 が非常に低い值で破壊する。これは破壊点が供試体の 中心部分から離れて発生していることからも, また, 破 壊後, 供試体の中心軸がずれていることからもわかり, 偏心荷重が加わった所より破壊するため, 破壊位置の測 定は意味をなさなくなる。

管への応力の集中する箇所（破壊箇所）を特定するた め, 理論に合わせて左右対称とし, 管の破壊発生点を表 したものが図一3である. 盛り土等のない管のみにおけ る破壊位置は以上の実験結果より, 角度 0 度で 29 ケー ス中 6 ケースと高い頻度で発生している場合もあるが全 体的に発生しており，360度どこからでも破壊する可能 性があるという結果になった。

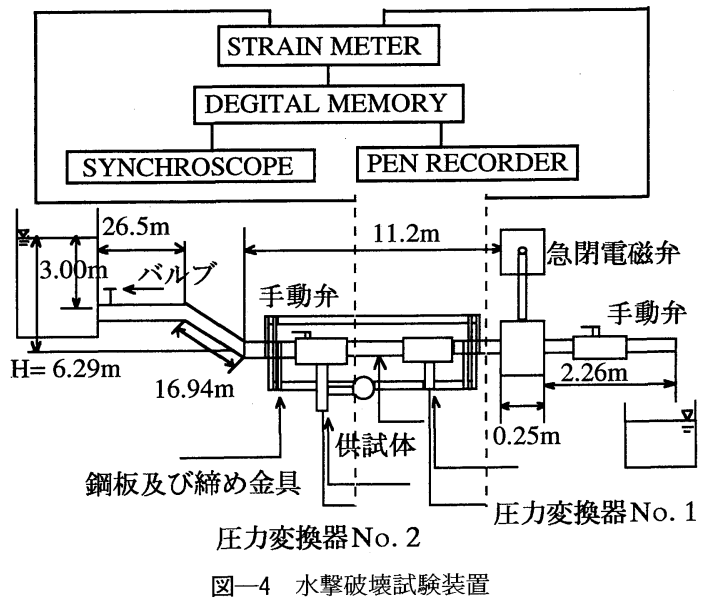

平面ひずみ問題としての二次元応力解析を行う場合, 軸方向への引っ張り力が加わらないものとして計算を行 うので, ケース 1 の軸方向への引つ張り力が加わらない ように供試体の両端を固定する場合の実験と条件が同じ であり実験結果と比較検討が出来る様になっている.

この破壊実験は水圧の計測, 管の断面における破壊位 置の測定とともに, 破壊した破片の大きさと数量, 破片 の飛距離, および, 破壊箇所から飛び散った水の到達距 離, および飛散状況についても同時に記録したが, 本研 究の目的よりはずれるので特徴のみを短く記す。これに よると, 破片の最大は $140 \mathrm{~mm} \times 55 \mathrm{~mm}$, 最大破片数は 12 個, 破片の最大飛距離は $201.6 \mathrm{~cm}$ （管径の 40.3 倍, 破片 $24 \mathrm{~mm} \times 8 \mathrm{~mm})$ ，および，破壊箇所から飛び散った 水の最大到達距離は $293.0 \mathrm{~cm}$ (管径の 58.6 倍）であっ た。

\section{4. 水撃圧による動的破壊試験}

\section{（1）水撃破壊試験装置と実験方法}

図一4 は水撃圧による塩化ビニール管供試体の破壊装 置で落差 $6.29 \mathrm{~m}$ を利用し, 水道用鋼管（管径 $50 \mathrm{~mm}$ ) の延長 $57.15 \mathrm{~m}$ を自然流下式にて流下した水は下の水 槽に溜められ，ポンプで上の水槽に送られる様になって いる. 平均流量並びに管の平均流速は下の水槽に流入し た水の体積及び流入時間を測定することにより求められ る.

水道用鋼管の下流端には急閉弁が設置され，その上流 部 $46 \mathrm{~cm}$ の所に静圧破壊試験に用いられたと同じ塩化 ビニール管の供試体が取付けられ, その両端に 1 個づつ 圧力変換器が取付けられている. 流速の調整は急閉弁の 下流側 $19.5 \mathrm{~cm}$ の位置に設置された手動弁によって行わ れる.

遮断弁で急激に閉鎖されることによって発生した水撃 


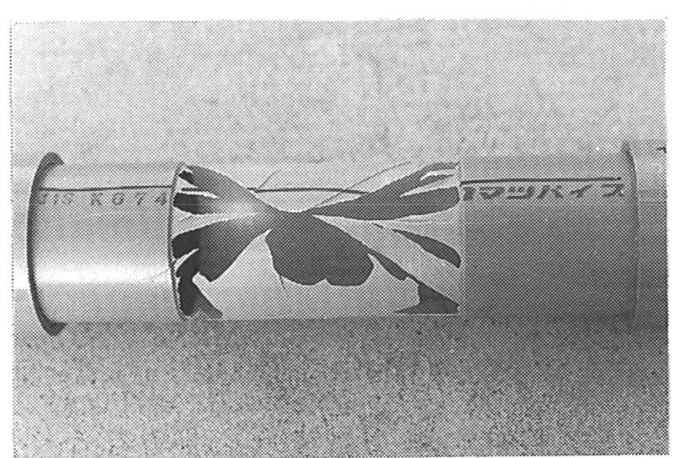

写真一4 水撃圧による供試体の破壊

圧は供試体の両端に設けられた圧力変換器によってピッ クアップされ, 動歪計にて増幅された後, 波計記憶装置

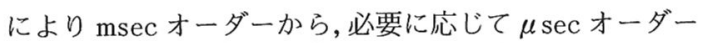
にて $4 \mathrm{k}$ words 分記憶される. 記憶された圧力波形はシ ンクロスコープでチエックした後ペンレコーダーにて書 き出され, すぐに最大圧力と圧力の継続時間が計算され るようになっている. 弁閉鎖後, 発生した水撃波は管の 上流端までの往復する時間が弁直前での載荷時間である が，ここでは供試体の破壊によって，急激に圧力が 0 上 なり途中で波形が途切れる.

供試体の下流部に設けられたNo.1 圧力変換器によっ て破壊した圧力までの波形が描きだされ, 供試体の上流 部に取付けられたNo. 2 圧力変換器によって供試体が破 壊する直前までに通過した圧力波形が描きだされる。ま た, 供試体に軸方向への引つ張り力が加わらないように 遮断弁は固定してある。

\section{（2）水撃破壊実験結果}

水撃圧による供試体の破壊は写真一4のように準静的 破壊試験の結果と非常に良く似た破壊パターンを示し た.しかし, その相違点としては, 準静的破壊の場合は 徐々に載荷されることにより，管も徐々に白く膨らみ， 破壊線が軸方向に走り，破壊点から四方にX型に破壊す るのであるが，水撃圧による供試体の破壞は一瞬のうち に破壊するため, 供試体には白く, 膨れた跡はあまり残 らず激しくX型に破壊している.

水撃波形が図一5 の様に圧力が徐々に増加して破壊寸 前に最大圧力となる場合や理論值のように矩形波ならば 発生した最大水撃圧が破壊圧力となる。しかし, 図一6 のように始めに最大水撃圧が発生し, それが半周期の間 に小さな減衰振動を繰り返しながらある時点で破壊する 場合, どの圧力をもって破壊圧力とするか疑問点があり, また，供試体に繰り返し荷重が加わったことにもなるの で実験結果には採用していない,このようなケースは最 大值にて供試体が破壊せず供試体が伸縮した場合や入力

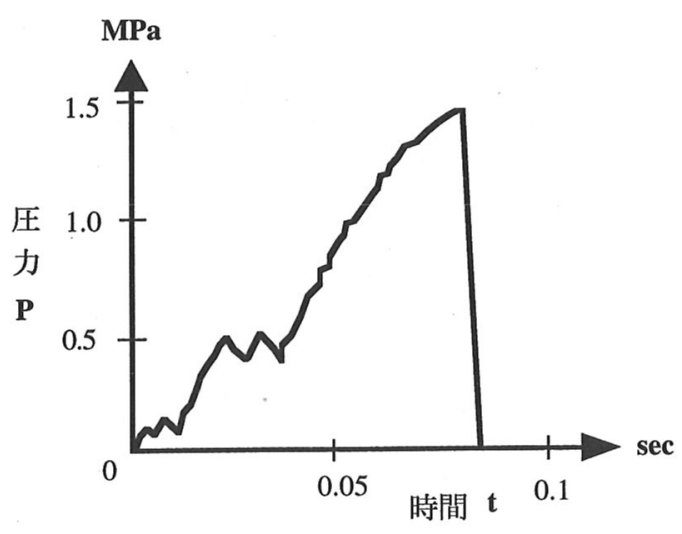

図一5 水撃圧が徐々に増加する場合

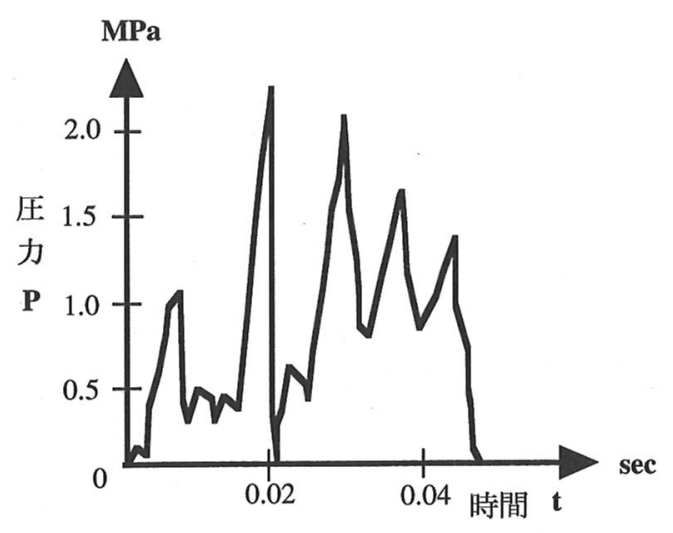

図一 6 水撃圧の最大值が先にくる場合

する水撃波の高い場合で水撃圧発生による管の振動が水 撃波形へ重複した場合などであり, 最大值でちょうど供 試体が破壊するように流速を調整しなければならない。 水撃破壊圧力として実験結果より採用するデー夕は供試 体に偏心荷重や引つ張り力のない, そして上の条件を満 たした実験結果でなければならない.

また, No. 2 変換器の出力波形のみを計測すれば管の 破壊圧力および載荷時間が求められると思われたが, 実 際は水撃波速が 20 回の平均で $1270 \mathrm{~m} / \mathrm{s}$ となり, 管の 破壊速度 (これは計測していないが) より速く管が破壊 する前に通過してしまうため, 出力波のみによって破壊 圧力を計測することは供試体の長さ $30 \mathrm{~cm}$ のような短 い供試体では不可能であることが数多くの試験により判 明した. しかし，その計測法としては管内の流速をコン トロールし, 弁閉鎖により発生する水撃圧を徐々に下げ 最低值によって破壊する圧力を求めることにより可能で ある.ただし，それには入力波と出力波が一致して供試 体が破壊する圧力と載荷時間を計測しなければならず, この試験方法は難しく, 熟練したうえで 3,4 割の結果 が出来れば上々である. 


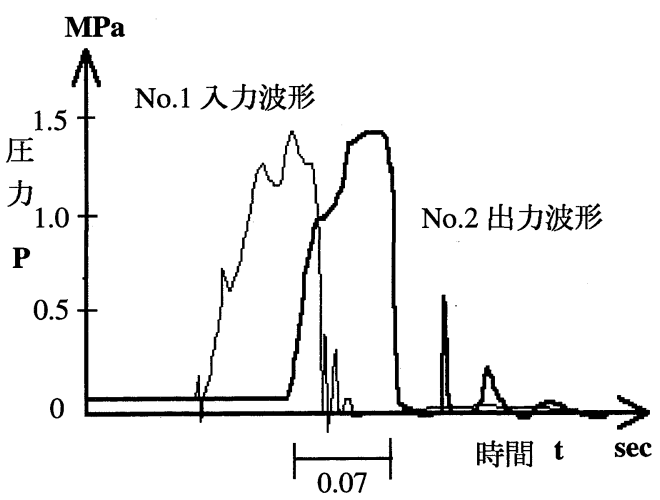

図一7 水撃波形（入力波と出力波）

よって, 供試体の上流部に設けられた No. 2 変換器と 下流部に設けられた No.1 変換器とによってピックアッ プされた最大水撃圧が図一7のように，一致したデータ のみを採用している．これは水撃圧が塩化ビニール管の 供試体を通って伝幡するため上流部では水撃圧が少し減 衰するがほぼ等しい值を示していなければならない。こ のように, No.1 (入力波) と No.2 (出力波) 地点の水 撃波形が一致し，上で述べた偏心荷重の加わらない等の 条件を満たした試験結果 20 回の破壊圧力の平均值は $14.55 \mathrm{kgf} / \mathrm{cm}^{2}(1.427 \mathrm{MPa})$ となった.

準静的破壊試験と水撃破壊試験との結果の比較検討と しては, 準静的破壊試験の結果は破壊圧力 $11.57 \mathrm{kgf} /$ $\mathrm{cm}^{2}(1.137 \mathrm{MPa})$ となり，水撃破壊試験の破壊圧力は $14.55 \mathrm{kgf} / \mathrm{cm}^{2}$ (1.427 MPa) となった. つまり, 水撃圧 による動的破壊試験の結果の方が $2.98 \mathrm{kgf} / \mathrm{cm}^{2}(0.292$ $\mathrm{MPa}$ ），いわゆる $25.8 \%$ だけ準静的破壊試験より高い 圧力で破壊する結果となった．この時，準静的破壊試験 の載荷時間が約 2 分間（120 秒間）に対して，水撃破壊 試験の載荷時間は 0.07 秒と約 2000 倍の差となってい る.

水撃圧による破壊点の発生する位置は図一8のように なり， 0 度にて 3 回の高い頻度があるとは言え, 準静的 破壊試験結果之同梯, ぼの角度からでも破壊が発生する 可能性があることを示している.

この両試験の結果において, 破壊圧力に差異が生じた 理由の一つには, 供試体の材料である塩化ビニール管の 静的, 準静的強度に対して, 動的破壊では材料の構成則 が変化し, つまり, Timoshenko ${ }^{7)}$ によると動的強度が 見掛け上上昇するためである.もう一つの理由に，水撃 圧の波速が約 $1300 \mathrm{~m} / \mathrm{s}$ に対し, 前に述べたとおり，塩 化ビニール管の破壊速度，つまり管の応答速度が遅いた め, 破壊するためには準静的破壊試験より高い圧力が必 要となるためで, 写真一2 の準静的な水圧によって破壊 し白く膨らんだ跡のある供試体と写真一 4 の動的な水撃

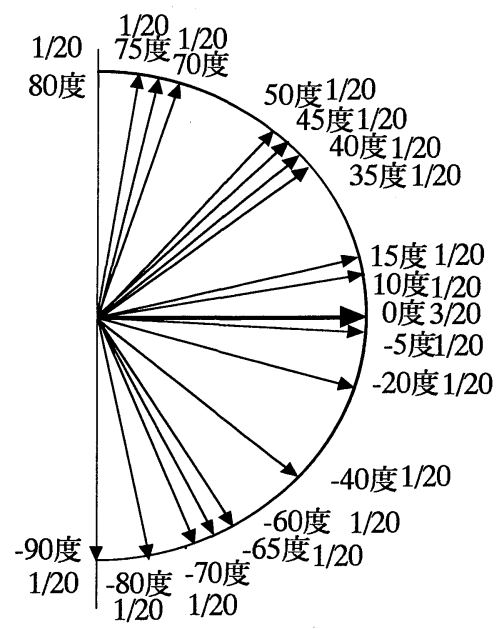

図一8 水撃破壊発生点の位置と頻度

圧によって破壊した供武体からも推測出来るように，慣 性項の影響が強くなるためで8), 以上の二つの理由また はこれらの複合された原因によるものと考えられるが, これらは大きな研究テーマであり, 今回の研究において は両試験の試験方法や問題点その結果としての破壊圧力 の差異などの提示に留め, それらの原因の究明等に関し ては今後の課題としたい.

\section{5. 水撃理論}

\section{（1）水撃波伝播速度}

この実験管路は水道用鋼管で出来ており，供試体のみ 必要な材質で作製し, 組み入れるようになっているので, 水撃波の伝播速度 $a$ は境界条件が水道用鋼管の両端固 定における式を用い，次式で表される ${ }^{11)}$.

$$
a=\sqrt{\frac{\frac{K}{\rho}}{1+\left(\frac{K}{E}\right)\left(\frac{D}{e}\right)\left(1-\mu^{2}\right)}}
$$

ここで, $D$ : 管の内径 $50 \mathrm{~mm}, e$ : 管の肉厚 $3 \mathrm{~mm}, K$ : 水の弾性係数 $2.07 \times 10^{8} \mathrm{kgf} / \mathrm{m}^{2}(2.03 \mathrm{GPa}), \rho$ : 水の 密度 $101.97 \mathrm{kgf} \cdot \mathrm{s}^{2} / \mathrm{m}^{4}\left(1000 \mathrm{~kg} / \mathrm{m}^{3}\right), E$ : 管の弾性係 数 $2.0 \times 10^{10} \mathrm{kgf} / \mathrm{m}^{2}(196 \mathrm{GPa}), \mu$ : ポアソン比 0.3 の 値を式（1）に代入すると伝播速度 $a$ は $1325 \mathrm{~m} / \mathrm{s}$ とな る. 実験では伝播速度は $1270 \mathrm{~m} / \mathrm{s}$ となり, 解析結果お よび実験結果とも約 $1300 \mathrm{~m} / \mathrm{s}$ と比較的一致した值が得 られている.

\section{（2）水撃压の理論解析}

管内の流れの変化を解析するために管に沿って座標軸 を設定する. その座標上の位置を表す変数を $x$, 時間を 表す変数を $t$ とする. その時に流速 $V$ と圧力水頭 $H$ の 
$x$ と $t$ に対する変化は次の運動方程式と連続方程式に よって表される.

$$
\left.\begin{array}{l}
V_{t}+V V_{x}+g H_{x}+\frac{f V|V|}{2 D}=0 \\
H_{t}+V H_{x}-V \sin \alpha+\frac{a^{2}}{g} V_{x}=0
\end{array}\right\}
$$

ここで, $f$ は摩擦係数 $0.02, \alpha$ は管の傾斜角, $D$ は管 の直径 $50 \mathrm{~mm}, g$ は重力の加速度を表す. 式 (2) に対 する数值計算法としては, 特性曲線の方向への解の変化 を計算する方法が良く知られている ${ }^{11)}$.

ここでは， $(x, t)$ 平面上に長方格子を設定し, 各格 子点における解の近似値を差分方程式の解として計算す るという, 従来の特性曲線を利用する方法とは異なる方 法を用いて数值解析を行う.

式（2）における運動方程式と連続方程式は 1 階の準 線形偏微分方程式系を構成する.ここで，

$$
v=\left(\begin{array}{c}
V \\
H
\end{array}\right), \quad A=\left[\begin{array}{cc}
V & g \\
\frac{a^{2}}{g} & V
\end{array}\right], \quad h=\left(\begin{array}{c}
-\frac{f V|V|}{2 D} \\
V \sin a
\end{array}\right)
$$

とすると式 (2) は

$$
v_{t}+A v_{x}=h
$$

となる. 行列 $A$ は 2 つの異なる実数の固有值 $V-a, V$ $+a$ を持つので式 (2) は双曲線型である. 1 階の双曲 型準線形偏微分方程式系に対しては, 差分法を用いた数 値計算法が文献 ${ }^{2)}$ で紹介されている.その中でも特に長 方格子上の格子点における解の近似值を計算する方法を ここで応用する. 行ベクトル

$$
l^{-}=\frac{1}{\sqrt{a^{2}+g^{2}}}(a,-g), \quad l^{+}=\frac{1}{\sqrt{a^{2}+g^{2}}}(a, g)
$$

は固有值 $V-a, V+a$ に対応する固有ベクトルである. 即ち, $l^{-} と l^{+}$は

$$
l^{-} A=(V-a) l^{-}, \quad l^{+} A=(V+a) l^{+}
$$

を満足する. 固有ベクトル $l^{-} と l^{+}$を式 $(3)$ の両辺に 掛けることにより次の 2 つ式が得られる.

$$
\begin{gathered}
l^{-} v_{t}+(V-a) l^{-} v_{t}=l^{-} h, \\
l^{+} v_{t}+(V+a) l^{+} v_{t}=l^{+} h
\end{gathered}
$$

ここで, $a$ と $g$ が定数であることに注意すると,

$$
\left.\begin{array}{l}
Y=l^{-} v=\frac{1}{\sqrt{a^{2}+g^{2}}}(a V-g H) \\
Z=l^{+} v=\frac{1}{\sqrt{a^{2}+g^{2}}}(a V+g H)
\end{array}\right\}
$$

とおくことにより，これら2つの式は次のように式 ( 5 ) となることがわかる。

$$
\left.\begin{array}{l}
Y_{t}+(V-a) Y_{x}=-\frac{1}{\sqrt{a^{2}+g^{2}}}\left(\frac{a f V|V|}{2 D}+g V \sin \alpha\right) \\
Z_{t}+(V+a) Z_{x}=-\frac{1}{\sqrt{a^{2}+g^{2}}}\left(\frac{a f V \mid V}{2 D}-g V \sin \alpha\right)
\end{array}\right\}
$$

式（4）より $V$ と $H$ は

$$
\left.\begin{array}{l}
V=\frac{\sqrt{a^{2}+g^{2}}}{2 a}(Y+Z) \\
H=\frac{\sqrt{a^{2}+g^{2}}}{2 g}(-Y+Z)
\end{array}\right\}
$$

で与えられることがわかる.

ここで，管の長さが $L$ こき，ある自然数 $n$ に対して $\Delta x=L / n$ とする. 更に, ある $\Delta T>0$ を選ぶ. 式 ( 5 ) に対して差分法を応用するために $x_{i}=i \Delta x, i=0,1,2$, $\cdots, n, t_{j}=j \Delta t, j=0,1,2, \cdots$ を満足する点 $\left(x_{i}, t_{j}\right)$ を 格子点亡する $(x, t)$ 平面上の長方格子を考える. 式 $(3)$ の解 $V, H$ 亡式 (5) の解 $Y, Z$ の格子点 $\left(x_{i}, t_{j}\right)$ に おける值を近似する差分方程式の解の值を $V_{i, j}, H_{i, j}$ と $Y_{i, j}, Z_{i, j}$ で表す。その場合に, 式（5）に対して前進 および後退差分を用いることにより次の差分方程式を得 る.

$$
\begin{aligned}
& \frac{Y_{i}^{j+1}-Y_{i}^{j}}{\Delta t}+\left(V_{i}^{j}-a\right) \frac{Y_{i+1}^{j}-Y_{i}^{j}}{\Delta x} \\
& =-\frac{1}{\sqrt{a^{2}+g^{2}}}\left(\frac{a f V_{i}^{j}\left|V_{i}^{j}\right|}{2 D}+g V_{i}^{j} \sin \alpha\right) \\
& i=0,1,2, \cdots, n-1, \quad j=0,1,2, \cdots \\
& \frac{Z_{i}^{j+1}-Z_{i}^{j}}{\Delta t}+\left(V_{i}^{j}+a\right) \frac{Z_{i}^{j}-Z_{i-1}^{j}}{\Delta x} \\
& =-\frac{1}{\sqrt{a^{2}+g^{2}}}\left(\frac{a f V_{i}^{j}\left|V_{i}^{j}\right|}{2 D}-g V_{i}^{j} \sin \alpha\right) \\
& i=1,2,3, \cdots, n, \quad j=0,1,2, \cdots
\end{aligned}
$$

管の上流端は貯水槽に接続され，下流端には弁が取付 けられた場合を考える. 上流端における圧力水頭は変化 せず，下流端の弁は一定の速度で閉鎖されると仮定して 解析を行う.

\section{（3）水撃解析結果と水撃破壊実験值との比較検討}

その結果は図一9のように理論的水撃解析結果では, 弁の閉鎖開始より完全閉鎖まで 0.015 秒かかるのである が，圧力は弁の閉鎖開始より立ち上がり始め 0.012 秒で ピークに達する, その後, 多少の上下動はあるが 0.07 秒までピークを維持し 0.051 秒で最大値 $16.86 \mathrm{kgf} / \mathrm{cm}^{2}$ (1.65 MPa) を示した後，急激に下降し 0.083 秒より 負圧に転ずる.

実験では水撃圧発生後, 同様に 0.027 秒かかってピー クに達し, その後, ピークを維持しながら供試体を押し 続け, 0.068 秒にて最大值 $14.5 \mathrm{kgf} / \mathrm{cm}^{2}(1.43 \mathrm{MPa})$ を示し供武体が破壊した。この実験での流速は 1.195 $\mathrm{m} / \mathrm{s}$ であった. 弁の急激な閉鎖 (0.015 秒) による水撃 波の立ち上がりは理論値および実験值とも良く似ている が理論値の方が急激な上昇を示した.

以上のように水撃理論の式（2）には管路の材質を考 


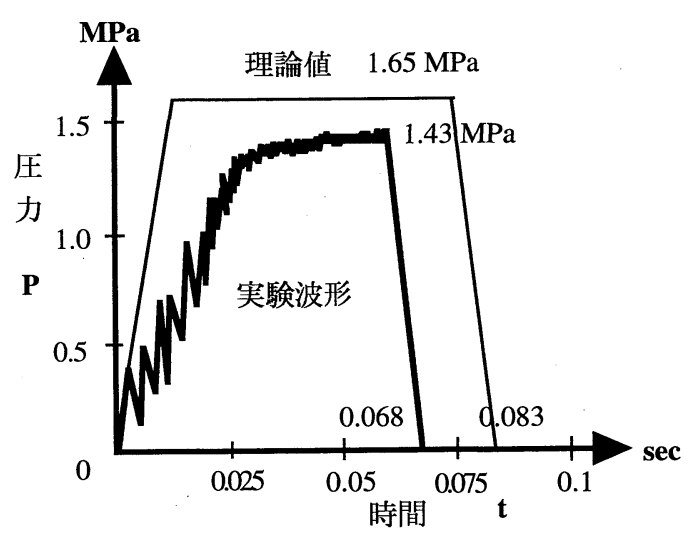

図一9 理論值と水撃破壊実験波形

慮に入れた水撃波の伝播速度を含んでいるが基本的には 流体の運動方程式と連続方程式であり, 塩化ビニール管 の破壊条件（慣性項や材料の動的構成則など）は含まれ ていない. それでも，解析された水撃理論值はこの管路 で弁閉鎖によって発生する水撃圧を示すものであり，供 試体に載荷する圧力との比較検討より，実際に供試体を 破壊させる水撃圧の発生条件である流速および載荷時間 に関係する管路長などが前もって決定される．それらを 考慮に入れての検討において，弁の閉鎖時間が 15/1000 秒程度の場合水撃圧は $27 / 1000$ 秒かかって急激にピー クに達し，その後管を押し続け 68/1000 秒で管を破壊 するのであり，準静的破壊実験 120 秒と比較するための 載荷時間はこの破壊にかかる時間をとり 0.068 秒とする 亡約 2000 倍の差があることになる.これは一般的管路 においては最悪の場合と考えられる. 一般的な水撃圧の 載荷範囲は, 急閉鎖の場合, 伝播速度 $a$ が管路を往復 する前に弁を閉鎖した場合で $2 L / a$ 秒で表されるのでは あるが，一般的な管路長 $L$ はこの実験管路より長く載 荷時間も長い場合が殆どである.また，圧力においては $2.24 \mathrm{kgf} / \mathrm{cm}^{2}(0.22 \mathrm{MPa})$ だけ実験值が理論值よりも 低い值で破壊した.

前にも述べたように，破壊圧力を測定するには，入力 波と出力波との一致した水撃圧の最も小さい圧力で破壊 したデータのみを採用するため, 管路長も流速も一定の 値で水撃波を発生するので, 理論值はもとより実験波形 は20回亡も図一9のような値となる. しかし, 予備実 験では管路長を $20 \mathrm{~m}$, 供試体の肉厚を $0.3 \mathrm{~mm}$ とし, 流速を（1） $0.59 \mathrm{~m} / \mathrm{s} ，(2$ ) $0.88 \mathrm{~m} / \mathrm{s} ，(3) 0.93 \mathrm{~m} / \mathrm{s}$, (4) $0.59 \mathrm{~m} / \mathrm{s}$ と変化して水撃波を発生させて供試体を 破壊した。 その実験波形と理論値とを示したのか図一10 である.この管路にて発生した水撃波が上流端への往復 にかかる時間, いわゆる載荷時間の最大が 0.03 秒であ るが，実験では破壊に要する載荷時間は図のように色々
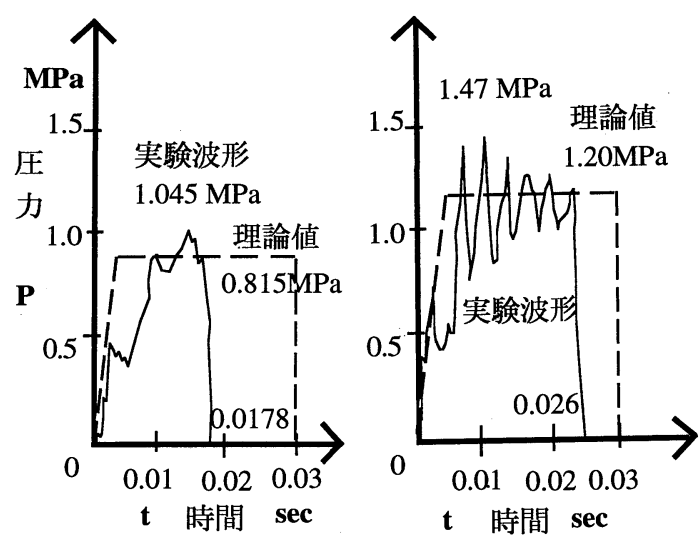

（1）流速 $0.59 \mathrm{~m} / \mathrm{s}$ における水撃波形

（2）流速 $0.88 \mathrm{~m} / \mathrm{s}$ における水撃波形
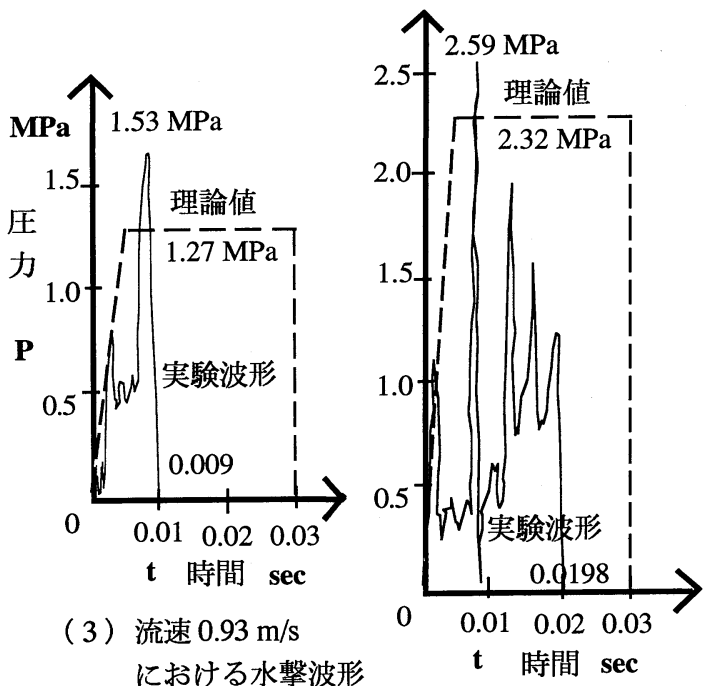

(4) 流速 $1.71 \mathrm{~m} / \mathrm{s}$ における水撃波形

図一10 流速変化による水撃波形

である．発生する水撃波の圧力は理論值と大体似た值を 示し, また, 破壊圧力は（1）から（4）までどの圧力 でも破壊し，圧力が高くなるにつれて波形が不安定にな る傾向にある.これも水撃圧の最低值で破壊させること にした理由の一つである. またこれらの予備実験より載 荷時間を長くするため管路長を約 $50 \mathrm{~m}$ とし，また供試 体の肉厚が薄いと偏心荷重が掛かり易く取付けなどが難 しいため肉厚を $0.4 \mathrm{~mm}$ と決定した.

\section{6. 水撃压による管の静的応力解析}

水撃圧による管の破壊に関する研究は水撃の難解さに 加え, 管の破壊も動的と考えられ未解決の部分が多い. 


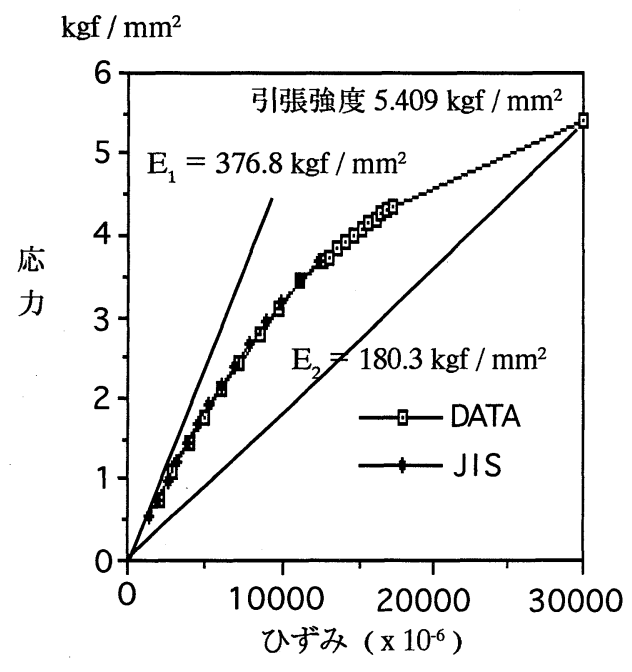

図一11 応力-ひずみ曲線

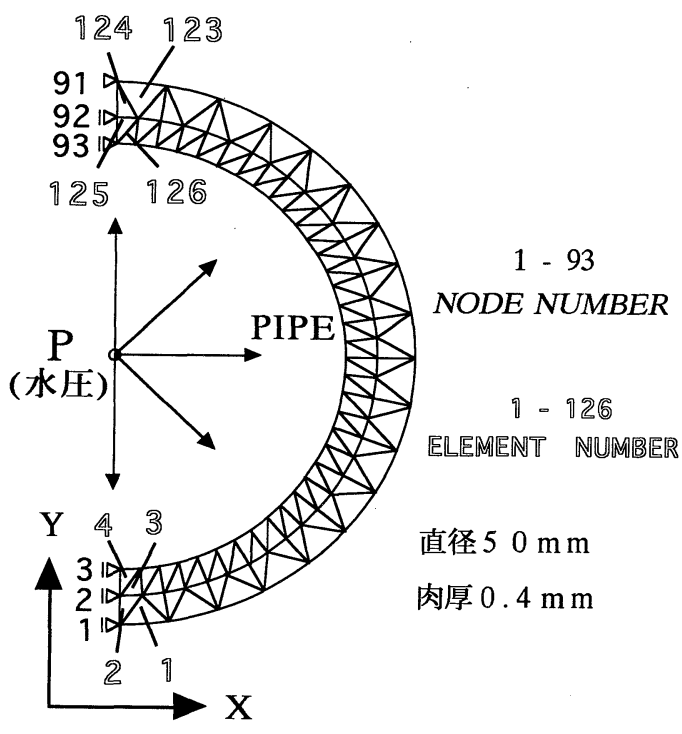

しかし，管の設計においては従来より静的と考え安全率 を考虑に入れ簡易計算がなされてきた。ここでは管内部 に作用する水撃圧を静的な水圧と仮定し, 静的応力解析 を試み, 実験值との比較検討より有限要素法を用いた静 的応力解析が水撃圧による管の破壊に関する研究によっ て，管の水撃作用開始から破壊に至るまでの挙動を知る など, 非常にメリットがあり, また，動的解析への足掛 かりとしても重要であることを示す.

\section{（1） 応力解析}

水撃圧が作用している管の変形・破壊を解析するにあ たって，管路軸直角方向の断面を対象とした平面ひずみ 状態について有限要素法を用いて行った.

解析は，管の水撃作用開始から破壊に至るまでの挙動 を知るために接線剛性増分法を用い, 最終載荷段階まで を 15 ステップで載荷するものとしている. 各ステップ において, 各要素の応力状態から弾性, 破壊の判定を行っ ている. 本解析においては 6 節点線形ひずみ三角形要素 を用いた。

\section{（2）塩化ビニール管の引張試験}

将来の動的引張試験への適用を考慮に入れて, JIS 規 格より小さい試験片を破壊実験に使用する塩化ビニール 管から切り出し, 重りを少しづつ載荷する試験装置を作 製し，静的な引張試験を行った．また，JIS 規格でも引 張試験を行った。その結果は図一11 の応力-ひずみ曲線 に示すようにほとんど同じ值となった。この応力ーひず み曲線より弾性係数は 10 回の平均で $1.8 \times 10^{4} \mathrm{kgf} / \mathrm{cm}^{2}$ （1.77 GPa）と $3.7 \times 10^{4} \mathrm{kgf} / \mathrm{cm}^{2}(3.63 \mathrm{GPa})$ の間の 值となり,引張強度は 7 回の平均で $\sigma=541 \mathrm{kgf} / \mathrm{cm}^{2}$
図-12 要素分割

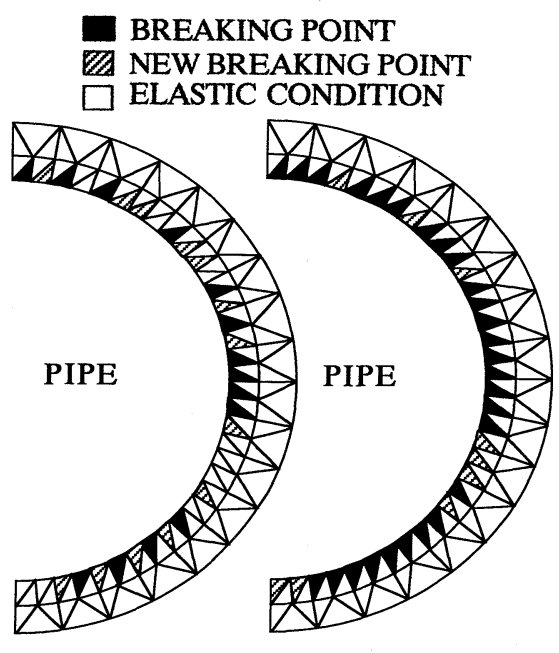

(1) STAGE 9 (2) STAGE 10

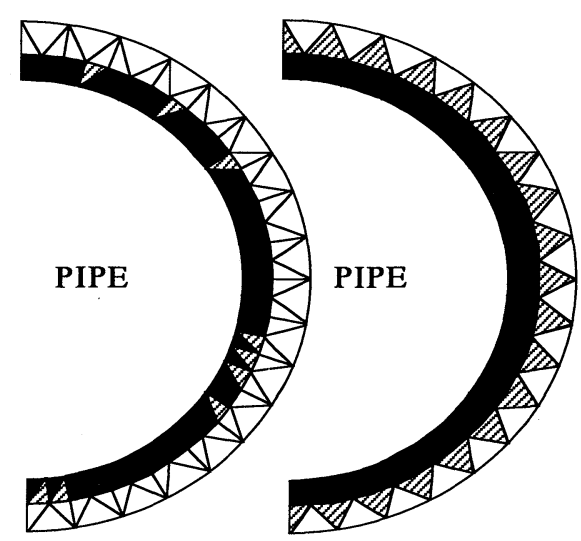

(3) STAGE 13 (4) STAGE 14

図一13 応力解析結果 
表一1 載荷時間および破壊圧力の比較

\begin{tabular}{|c|c|c|}
\hline & 載荷時間 & 破壊圧力 \\
\hline $\begin{array}{l}1 \text { 静的応力 } \\
\text { 解析結果 }\end{array}$ & $\begin{array}{l}\text { 無限 } \\
\end{array}$ & $\begin{array}{l}7.8 \mathrm{kgf} / \mathrm{cm}^{2} \\
(0.76 \mathrm{MPa})\end{array}$ \\
\hline $\begin{array}{ll}2 & \text { 準静的破壊 } \\
& \text { 試験結果 }\end{array}$ & 120 秒 & $\begin{array}{c}11.57 \mathrm{kgf} / \mathrm{cm}^{2} \\
(1.137 \mathrm{MPa})\end{array}$ \\
\hline $\begin{array}{ll}3 & \text { 水撃破壊 } \\
& \text { 試験結果 }\end{array}$ & 0.068 秒 & $\begin{array}{c}14.55 \mathrm{kgf} / \mathrm{cm}^{2} \\
(1.427 \mathrm{MPa})\end{array}$ \\
\hline $\begin{array}{l}(1 \& 2) \\
(2.7 \\
(2 \& 3) \\
(1 \& 3)\end{array}$ & $\begin{array}{c}\text { 压力差 } \\
\mathrm{kgf} / \mathrm{cm}^{2}(0.370 \\
\mathrm{kgf} / \mathrm{cm}^{2}(0.292 \\
\mathrm{kgf} / \mathrm{cm}^{2}(0.662\end{array}$ & 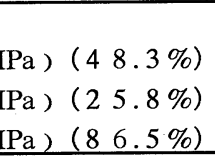 \\
\hline
\end{tabular}

(53.01 MPa) となった.

\section{（3）管の構成式とモデル化}

解析対象となる塩化ビニール管の引張試験より弾性係 数 $E=3.1 \times 10^{4} \mathrm{kgf} / \mathrm{cm}^{2} \quad(3.04 \mathrm{GPa})$, ポアソン比 $\mu=$ 0.37 , 破壊応力 $\sigma=541 \mathrm{kgf} / \mathrm{cm}^{2}(53.01 \mathrm{MPa})$, せん断 弾性係数 $G=1.19 \times 10^{4} \mathrm{kgf} / \mathrm{cm}^{2}(1.17 \mathrm{GPa})$ の弾性体 として解析を行った.

管の断面を図一12に示すように管の直径は $50 \mathrm{~mm}$, 肉厚 $0.4 \mathrm{~mm}$, 総節点数 93 , 総要素数 126 のように要素 分割を行った. 載荷荷重は管内に最大 $10 \mathrm{kgf} / \mathrm{cm}^{2}(0.98$ $\mathrm{MPa})$ が作用するものとして, 載荷荷重を増加させる ことによって管のみの破壊水圧を解析している．境界条 件としては，節点番号 91 を拘束し，節点番号 $1,2,3$ 及び 92,93 を方向変位拘束境界とした.

\section{(4) 解析結果}

水圧が管に作用している場合についての解析結果は各 ステージごとに引張強度に達した要素が黒く塗られ, 図 -13 ( 1 ) stage 9, ( 2 ) stage 10, ( 3 ) stage 13, ( 4 ) stage 14 で示されるように管の水撃作用開始から破壊に 至る傾向が表わされ，破壊する方向に関しては等方性が 示され, 破壊圧力は $7.8 \mathrm{kgf} / \mathrm{cm}^{2}(0.76 \mathrm{MPa})$ となった.

\section{7. 解析結果と実験結果の比較と考察}

本研究では水撃圧による管の動的破壊と水圧による準 静的破壊との差異を明らかにすることを目的とし，これ までとは異なる差分による水撃解析および管の破壊に関 する解析法を開発し, 静的応力解析適用上の安全性およ びメリット等について検討を行った. 本研究によって行 われた解析結果と実験結果の比較および考察は以下のと おりである。

（1）準静的破壊試験と水撃破壊試験および静的応力 解析結果との比較を表一1 に示した，その比較検討とし
ては, 準静的破壊試験の結果は破壊圧力 $11.57 \mathrm{kgf} / \mathrm{cm}^{2}$ $(1.137 \mathrm{MPa})$ となり，水撃破壊試験の破壊圧力は $14.55 \mathrm{kgf} / \mathrm{cm}^{2}(1.427 \mathrm{MPa})$ となった.つまり, 水撃 圧による動的破壊試験の結果の方が $2.98 \mathrm{kgf} / \mathrm{cm}^{2}$ $(0.292 \mathrm{MPa})$ ，いわゆる $25.8 \%$ だけ準静的破壊試験 より高い圧力で破壊する結果となった．この時，準静的 破壊試験の載荷時間が約 2 分 (120 秒) に対して, 水撃 破壊試験の載荷時間は 0.068 秒と約 2000 倍の差となっ ている. また, 静的応力解析結果としては破壊強度が $7.8 \mathrm{kgf} / \mathrm{cm}^{2}(0.76 \mathrm{MPa})$ となり, 破壊する方向に関し ては等方性が示された. 破壊する方向に関しては準静的 破壊試験の結果についても, 水撃破壊試験結果について も同様に等方性を示した. 静的応力解析結果と準静的破 壊試験結果との差は $3.77 \mathrm{kgf} / \mathrm{cm}^{2} \quad(0.370 \mathrm{MPa})$ $(48.3 \%)$ となり，水撃破壞試験結果との差は 6.75 $\mathrm{kgf} / \mathrm{cm}^{2}(0.662 \mathrm{MPa})(86.5 \%)$ となった.

（2）理論的水撃解析では伝播速度は $1325 \mathrm{~m} / \mathrm{s}$ とな り，弁の閉鎖開始より完全閉鎖まで 0.015 秒かかるが, 圧力は弁の閉鎖開始より立ち上がり始め 0.012 秒でピー クに達する. その後, 多少の上下動はあるが， 0.07 秒 までピークを維持し 0.051 秒で最大值 $16.86 \mathrm{kgf} / \mathrm{cm}^{2}$ (1. $65 \mathrm{MPa})$ を示した後, 急激に下降し 0.083 秒より 負圧に転ずる.

それに対して, 実験では伝播速度は $1270 \mathrm{~m} / \mathrm{s}$ となり, 水撃圧発生後, 同様に 0.027 秒かかってピ一クに達し, その後, ピークを維持しながら供武体を押し続け, 0.068 秒にて最大值 $14.5 \mathrm{kgf} / \mathrm{cm}^{2}(1.43 \mathrm{MPa})$ を示し 供試体が破壊した.この実験での流速は $1.195 \mathrm{~m} / \mathrm{s}$ で あった．弁の急激な閉鎖（0.015 秒）による水撃波の立 ち上がりは理論値および実験值とも非常に良く似てい る. 準静的破壊実験の載荷時間 120 秒と比較するため, この破壊にかかる時間を 0.068 秒とすると載荷時間の差 は約 2000 倍となる.このような弁の急閉鎖は一般的管 路においては最悪の場合である.

本実験より，水撃圧による動的破壊試験の結果の方が $2.98 \mathrm{kgf} / \mathrm{cm}^{2}(0.292 \mathrm{MPa}), 25.8 \%$ だ準静的破壊試 験より高い圧力で破壊する結果となり, 設計上安全側と なることがわかった。

以上の結果より，一般的な載荷範囲の急閉鎖ならば, 塩化ビニール管において, 水撃圧による動的破壊も, 静 的応力解析および弾塑性解析によって充分に表現出来え るものと考えられる。

（3）水撃圧による動的破壊が, 静的応力解析および 弾塑性解析で充分表現し得るとした場合，これまでにほ とんど解析が出来なかった水撃圧による管の破壊状況や 破壊事故の解析，水撃圧による埋設管の破壊状況および 盛土や地盤の塑性化状況等が解析可能となる. また, 逆 に管の破壊状況より，管の破壊をもたらした水撃圧の発 
生を弾性解析および弾塑性解析と水撃解析より求めるこ とも可能となることが明らかとなった5).

（4）破片 $(24 \mathrm{~mm} \times 8 \mathrm{~mm})$ の最大飛距離は201.6 $\mathrm{cm}$ (管径の 40.3 倍) で, 破壊箇所から飛び散った水の 最大到達距離は $293.0 \mathrm{~cm}$ (管径の 58.6 倍) であった. この結果より, 直ちに破片が定量的に管径の約 40 倍, 水は約 59 倍程飛ぶ亡は言えないが, 破壊が発生した場 合, 管の破片および流出した水が想像以上に遠くまで達 し, 大きな被害を与え, 時には人的被害をもたらす可能 性を示している5 .

（5）準静的破壊試験および水撃破壊試験において, 供試体の最も薄い部分から破壞するが, その亀裂は厚さ $2 \mathrm{~mm}$ の部分にまで簡単に達する. 特に引つ張り力が働 く場合には, $7.7 \mathrm{kgf} / \mathrm{cm}^{2}(7.55 \mathrm{MPa})$ の様な低い圧力 で破壊する時にでも, 亀裂は厚さ $2 \mathrm{~mm}$ の部分を走り, 塩化ビニール管とソケットとを接着した最も厚い約 7.5 $\mathrm{mm}(0.3 \mathrm{~mm}$ の 25 倍）の部分やそれ以上のねじの部分 までも破壊される場合がある。この事より圧力はそれほ ビ高く無くとも，材質の欠陥や初期不整の影響で，ある 一点で破壊が始まれば他の強度の高い部分までもが破壊 することがわかる. 故に, 高い圧力が発生するような管 路や重要管路においては材質の欠陥や初期不整に十分注 意を要する.

\section{8. 結 論}

（1）水撃圧の解析に上流差分法の適用がはじめて試 みられた。これは本研究での流体における水撃解析ばか りでなく,これまでの特性曲線法では解決不可能であっ た水撃負圧部の気液混相流問題における非線形部の解析 への道を開いた。

（2）塩化ビニール管の準静的破壊および水撃破壊に 対して, 水撃圧および圧力を静的水圧と仮定して静的応 力解析を適用することにより，これまで未知であった水 撃圧による管破壊の挙動が明らかとなり, 管破壊事故の 状況および埋設管などへの適用等の可能性がでてきた. 安全率を考慮にいれての簡易計算はこれまでも行われて きたことで, 準静的破壊および水撃破壊に対して, 静的 応力解析を適用することは可能で, それにより多くのメ リットがあることが明らかとなった。 しかし, 準静的破 壊実験と静的応力解析で載荷時間と破壊圧力の差があ り, また静的応力解析と水撃破壊実験においても破壊圧 力の差は $86.5 \%$ となった. 水撃破壊実験の結果を見る
と動的解析による慣性項の影響による振動に似た波形が 出ている. 今後の課題としては静的応力解析で対応出来 る範囲と慣性項が大きくなり動的解析をしなければなら ない範囲とを明らかとし，慣性項を含めた水撃圧による 管の動的破壊解析の研究が必要である.

最後に，本研究を行うに当たり初期の段階で文部省科 学研究費の補助を得た。 また, 本論文の取りまとめに当 たりパイプラインの水撃専門家である農林水産省農業工 学研究所の島田正志氏にご指導いただいた.ここに記し 感謝の意を表します.

\section{参考文献}

1) Britto, A.M. and Gunn, M.J. : Critical state soil mechanics via finite elements, JohnWiley \& Sons, 1987.

2) Courant R., Issacson E. and Rees : On the solution of nonlinear hyperbolic differential equations by finite differences, Comunications on Pure and Applied Mathematics, pp.243-255, 1952.

3) Davidson, J.W. and Goulter, I.C.: A new probability distribution to model water main breakage patterns, Proceeding of international conference on water pipeline systems, Mechanical Engineering Publications Ltd, 1994.

4) Heinsbroek, A.G.T.J. : The infruence of support rigidity on waterhammer pressures and pipe stresses, Unsteady Flow and Fluid Transients, pp.43-52, 1992.

5) Kono, Y., Sugano, T. and Sugai, Y. : Analysis of penstock fracture by water hammer, Pipeline Systems, pp.165-170, 1992.

6）河野幸夫, 菅井幸仁：特性曲線法による水撃解析と有限 要素法による圧力トンネルの静的応力解析, 第 29 回水理 講演論文集, pp.657-662, 1985.

7) Timoshenko, S.P. and Young, D.H. : Elements of Strength of Materials, Van Nostrand Company, INC., p.377, 1968.

8）戸部俊美, 佐藤裕久, 高津宣夫 : 円管の高速張出し変形 に関する一考察, 塑性と加工, 第 25 巻第 283 号, pp. 716-722, 1984.

9) Tullis, J.P. and Watkins, R.K. : Pipe collapse caused by a pipe rapture-a case study, Proceeding of international meeting on hydraulic transients with water column separation, Universidad Politecnica de Valencia, pp.319-333, 1991.

10）渡辺雅二，河野幸夫：数值計算による管内気液 2 相流の 水撃解析、日本応用数理学会平成 5 年度年会講演予稿集, pp. 59-60, 1993.

11) Watters, C.Z. : Modern analysis and control of unsteady flow in pipelines, Ann Arbor Science, p.251, 1979.

(1993.12.14 受付) 
EXPERIMENTAL STUDY ON DYNAMIC FRACTURE OF PIPES BY WATER HAMMER AND QUASI-STATIC FRACTURE BY WATER PRESSURE

\author{
Yukio KONO, Takahiro SUGANO and Masaji WATANABE
}

The stress analysis and fracture analysis of pipeline by water hammer has seldom been studied because water hammer effect is the dynamic phenomena except the water hammer created by gradually closed valve in a long line. In this research experiments of pipe fracture were conducted in order to examine the difference between the strength of the PVC test pipes by water hammer in about 0.07 second loading and by static pressure in about two minutes loading. The pressure of dynamic fracture by water hammer was about $25 \%$ higher than the static fracture, though the loading time difference is 2,000 times. From this result it is possible that the static stress analysis could be applied to the pipe to the pipe fracture by water hammer even in a case of sudden valve closure. 